\title{
AAAS criticized over AIDS sceptics' meeting
}

Washington. The American Association for the Advancement of Science (AAAS) has come under fire from US AIDS researchers and public health officials for its sponsorship of a meeting in San Francisco next month at which speakers will dispute the link between HIV and AIDS.

The meeting's title, "The role of HIV in AIDS: why there is still a controversy", is very similar to that being held by the Sunday Times in London next week (see below). It is due to take place on 21 June as part of the annual meeting of the Pacific Division of the AAAS. Speakers include Peter Duesberg of the University of California, Berkeley, the chemist Kary Mullis and nine others. But as criticism of the line-up mounted, AAAS executive officer Richard Nicholson indicated that the session might be called off. "All options are still open, including cancellation," Nicholson said on Monday.

Critics of the meeting say that nearly all the speakers, who include both scientists and journalists, are known to share Duesberg's scepticism about the role of HIV in AIDS. "This is a real fringe of people surrounding Peter Duesberg who have been saying these things for a while now," says Bernie Fields, professor of microbiology at Harvard Medical School. "AAAS sponsorship makes it sound like a real issue when it's not; I think it's a disgrace."

David Baltimore of Rockefeller University, New York, says he cannot understand why the AAAS has allowed itself to sponsor

\section{. . . as UK prepares for Mullis encounter}

London. Britain's Sunday Times has called in Kary Mullis (right), the Californian scientist who invented the polymerase chain reaction (PCR) technique, to back its claim that critics of the theory that HIV causes AIDS have not been given a fair hearing in the scientific press.

Mullis is one of a group of scientists, based in California, who argue that there is insufficient evidence to identify HIV as the 'cause' of AIDS. The newspaper has organized a public meeting in London next week at which Mullis has said that he will mount a broad attack on the way in which much scientific research is managed.

Using as an example not only AIDS but also topics such as global warming, he is expected to argue that many researchers overdramatize the importance of various social problems in order to obtain research grants and further their academic careers. According to Mullis, these have become incentives for researchers to make "false assumptions" about such topics.

But the meeting comes at a time of growing concern among those actively engaged in caring for AIDS patients, both in developed and developing countries, that the Sunday Times's campaign, which draws its legitimacy from Mullis and others, is undermining public and political support for their efforts.

"The paper's campaign has been highly detrimental to AIDS work in this and other countries," says Nick Partridge, chief executive officer of the Terrence Higgins Trust in London, which provides support to AIDS patients. "The most serious impact of the campaign is that it allows those who wish to deny the impact of HIV [as a cause of AIDS] a way of doing so."

Similarly Sue Lucas, who coordinates the AIDS relief work of a number of British charities working in developing countries,

\section{IMAGE UNAVAILABLE FOR COPYRIGHT REASONS}

says that there is growing concern among non-governmental organizations in these countries that the Sunday Times's campaign "is encouraging people to think that there is not a problem".

Such concern has been fanned by reports that the British newspaper's coverage is beginning to influence public opinion in countries as far apart as Hong Kong and South Africa.

Supporters of the anti-HIV hypothesis claim that attacks on the newspaper can be dismissed, as they are put forward by those belonging to what they describe as the "AIDS establishment".

But Partridge and others claim that the anti-HIV camp has made rational discourse impossible, as it condemns anyone who criticizes their arguments as a member of a pro-HIV conspiracy.

Next week's debate, for which the Sunday Times has set an entry ticket at $£ 15(\$ 22.50)$ is entitled "Why there is still

But many scientists and AIDS workers see it as less of a scientific debate than a misguided effort to emulate the newspaper's pioneering efforts in unveiling scandals such as the thalidomide tragedies in the 1960s.

David Dickson an HIV-AIDS controversy". a meeting that does not represent scientific opinion. "This is a group of people who have denied the scientific facts," says Baltimore. "There is no question at all that HIV is the cause of AIDS. Anyone who gets up publicly and says the opposite is encouraging people to risk their lives.'

The meeting was organized by the AAAS Pacific Division in California, and had not come to the attention of senior AAAS officials in Washington until last week. Nicholson says that the Pacific Division will now "get some new advice" on the proposed session, and "look at it again from scratch."

The executive director of the AAAS Pacific Division, Alan Leviton, says that efforts are now being made to balance the panel. Since the initial line-up was published in a newsletter on 25 April, he has attracted one extra speaker — Gerald Lowenstein of the University of California Medical School at San Francisco - - and hopes to confirm two more this week. "I think we're well on our way to getting the additional people we'd feel more comfortable with," he says.

But the session organizer, Charles Geshekter of the California State University at Chico, says that balance is not his priority. "My responsibility is to create an interesting panel and a symposium that will boost attendance at our conference, and that's exactly what I'm hoping to do," he says. "My point wasn't so much balance, it was to generate controversy.'

Geshekter is an economic historian of Africa who will present a talk at the meeting entitled "The myth of African sexual promiscuity and misdiagnoses of AIDS in Africa". He says that he organized the meeting in reaction to uninspiring and badly attended AIDS sessions at the main AAAS annual meeting in San Francisco in February. "The argument has been dominated for ten years by one point of view," he says. "It is time to have a more robust debate."

Geshekter says he is "very heartened" by a recent article by Fields (see Nature 369 95 ; 1994) calling for new approaches to AIDS research. But Fields fears he is being misrepresented by the Duesberg school. "I'm not saying that there is a controversy [about HIV causing AIDS]," he says. "I'm saying that we need to broaden our understanding of the disease. I'd be very worried if my paper was playing a role in giving new life to this [Duesberg] view."

Michael Ascher, of the California Department of Health Services, and Warren Winkelstein, of the University of California at Berkeley, have written to the AAAS journal Science questioning the AAAS sponsorship because "some of the views to be expressed ... have potentially serious adverse public health consequences".

Colin Macilwain 